\title{
Tracing University of San Carlos' science and mathematics education graduates: How well are we in developing teacher professionals?
}

Cañizares, Monell John F.

College of Education Science and Mathematics Education Department, University of San Carlos - Cebu, Philippines (monelljohnz@gmail.com)

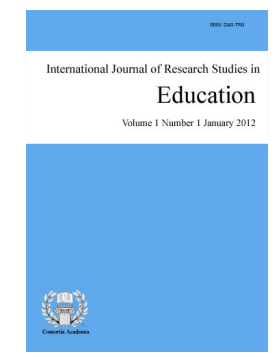

ISSN: 2243-7703 Online ISSN: 2243-7711

OPEN ACCESS

Received: 12 November 2014

Revised: 8 December 2014 Available Online: 4 January 2015 DOI: $10.5861 /$ ijrse.2015.985

Accepted: 3 January 2015

\section{Abstract}

Graduates were encouraged to develop personal skills and attitude that will prepare them in the field of work. This paper attempted to trace the Science and Mathematics Education (SME) graduates of the University of San Carlos, College of Education from AY 2009-2010 to AY 2011-2012 in order to determine the relevance of its curricular programs in meeting the needed manpower and the impending full implementation of the K-12 program. Cross-sectional retrospective survey which utilized a researcher-developed questionnaire in tracing the graduates was used in this study. A total of 65 SME graduates were identified within the specified period of time. Of these, 43 served as survey respondents with a response rate of $66.2 \%$. Data showed that the great majority of the respondents took and passed the Licensure Exam for Teachers (LET) in their first take, with two topnotchers and were mostly employed as full-time permanent teachers. Their retrospective evaluation of the curriculum indicated that its best aspect was the sequencing of the subjects. Graduates' perceived levels of professional efficacy showed that majority of the top rated character traits essential in their work has something to do with working with others. This study concluded that tracing the SME graduates revealed the institutional capability of the Science and Mathematics Education Department (SMED) and the relevance of its curricular programs. It is further recommended to update the current curriculum to be K-12 ready foreseeing that the future graduates should be developed to teach confidently in light of the Philippine educational reform.

Keywords: graduate tracer study; retrospective evaluation; cross-sectional survey; science and mathematics education; professional efficacy; Philippine educational reform 


\section{Tracing University of San Carlos' science and mathematics education graduates: How well are we in developing teacher professionals?}

\section{Introduction}

The launching of the $\mathrm{K}$ to 12 Basic Education Program (RA no.10533) is a major initiative of the government to overhaul the educational landscape of the Philippines. This change is intended to expand and enhance the basic education curriculum to improve its delivery and quality to meet international standards. Moreover, competent teacher professionals are needed in schools to promote positive student outcomes. Thus, the $\mathrm{K}$ to 12 educational reforms in basic education has important policy and practical implications to higher education, particularly among teacher education institutions (TEIs) in the pre-service and in-service training of teachers.

The Policy-Standard to Enhance Quality Assurance (QA) in Philippine Higher Education through an Outcomes-Based and Typology-Based QA (CHED CMO no. 46) issued by the Commission on Higher Education (CHED) is just one ripple effect of this reform. Significantly, it brought about concerns and actions of Higher Education Institution to re-evaluate its current curricular programs if it can still address the needs of our labor force in the coming years. One possible way of addressing this, is by conducting graduate tracer study (GTS) and find out essential feedback not only concerning the relevance of the course offerings but also the adequacy of the knowledge and skills gained by the graduates (Romillo \& Rodriguez, 2011). Tracer studies as what Ocholla emphasized (2001, cited in the study of Lutwama \& Kigongo-Bukenya, 2004), are important to educational institutions since it would enable them to accommodate changes in the society, especially the demands of the actual and potential employers, through the evaluation and constant review of the curricula.

One accrediting agency that evaluates and review academic programs in the Philippines, if it meets the standards of quality education is the Philippine Accrediting Association of Schools, Colleges and Universities (PAASCU) and it had recently visited USC-College of Education and had granted it accreditation for five years valid until November, 2017. One of its recommendation is for the college to conduct graduate tracer study (GTS) and find out if the current curricula is suited to the present and future job tasks of the graduates and if not, what changes needs to be effected. The college had already embarked to some GTS in the past but were done only to a few programs and batches in College of Education (COEd); hence, the need for a broader GTS that encompasses all programs of the college. Though the University as a whole had also done university wide GTS from batch 1981 to 2001 but it needs to be continued. Thus, during the year 2013 when this research study was conducted, in celebration of its 75th Anniversary of the college at that time and in response to the need in establishing accountability and relevance of its curricular program offerings, the USC College of Education (COEd) undertook this research program in order to provide a comprehensive database of its graduates over the past years as a means for improving the delivery of its curricular programs and student services, particularly in pre-service teacher education programs and its connections to their present line of work.

The intent of this Graduate Tracer Study (GTS) is to create an empirical portrait that describes the Science and Mathematics Education Graduates (in particular) of the College of Education (COEd) in the University of San Carlos (USC) during the academic year 2010 to 2012 in terms of their personal and professional characteristics and employability aspects in order to determine the relevance of USC COEd's curricular programs particularly in the field of Science and Mathematics Education in meeting the needed manpower for regional and national development. Moreover, it specifically intend to know the socio-demographic profile of the graduates, their educational background, professional exams taken and passed, graduate studies pursued and their employment status. Furthermore, it aims to trace the graduates' retrospective evaluation of their curricular program and educational experiences in the university and to gain insights of their perceived level of professional efficacy in achieving their career goals. 
It is vital for every institution to regularly conduct graduate tracer study (GTS) to monitor its graduates in terms of how they perform at work, how effective they are to do the tasks given to them and find out if they have meet their employer's expectations (Aina \& K. Moahi, 1999). Also, it is one way for the institution to gauge its curricular offerings in terms of its relevance and contributory effect to the needed manpower not only to the local or regional development but in terms of nation building as well. This is why an academic institution has to be consistent and should constantly review its curricular offerings to address the demands of the community it is serving. The relevance of the courses taken by its graduates to their work load and to what extent are they satisfied with their jobs, are a few of the findings you could get from survey studies and would serve as one of the basis for curriculum development.

Ingersoll (2012) and associates have recently undertook a study as to how pre-service teacher preparation affects teacher retention in the teaching profession. They asked the question whether the kind and amounts of education and preparation that new teachers receive before they begin teaching, can affect if they remain in teaching or not? Their study focuses on teachers in their first year of teaching, when attrition rate is highest and when the effects of pre-service preparation are most powerful. They looked at whether the beginning teachers stayed in teaching or left after their first year on the job and their findings are striking. The pre-service education and preparation that the new teachers received are strongly related to their retention, particularly in the field of math and science. They have found out that pedagogy is strongly related to teacher attrition. Beginning teachers who have taken more courses in teaching methods and strategies, learning theory or child psychology, or materials selection are significantly less likely to depart. The amount of practice teaching these teachers have undertaken, their opportunities to observe other teachers, and the amount of feedback they have receive on their teaching are also significantly related to whether they remain in teaching or not. Although it is important for teachers to have strong subject-matter knowledge, Ingersoll et al. (2012) suggests that adequate preparation in pedagogical methods and skills - the how of teaching-is also important in keeping teachers in the classroom. If we want to ensure that all students are taught by qualified science and mathematics teachers, retention is an important concern.

Indeed preparation of prospective teachers is one of the most contentious issues in education policy (Ingersoll, Merrill, \& May, 2012). Being able to assess the graduates' retrospective views and evaluation of their curricular program and their educational experience will help University administrators decide as to which aspects of the curriculum proved useful to their graduates. Belfield, Bullock, and Fielding (1999) argued that if institution can probe how their graduates felt their Higher Education Institution (HEI) contributed to their general development then they could better understand the different facets of the graduates' behavior. These facets as enumerated in their study are (1) securing a good income; (2) feelings of happiness, all things considered; (3) the development of new skills; (4) getting an interesting job; (5) the ability to face up to one' s problems; (6) the ability to communicate; (7) self-confidence; and (8) becoming a productive member of society. They further added that if institutions have knowledge of its individual graduates' views about their jobs (degrees), could indicate future supply of effort in the labor market (demand for more HE). Even in developing countries, higher education grows as a result of increasing demand, the need for qualified professionals, government pressure, the search for quality in higher education and increased access to higher education (Meyer \& Murphy, 2003, cited in Mainardes et al., 2010). Add to that the increasing competition between institutions, HEIs seeks way to survive.

The higher education market is becoming more and more competitive and organizations in the sector need the appropriate management tools to be able to survive in this complex market (Mainardes et al., 2010). One way to do it is to innovate particularly in offering new higher education courses that meet the specific needs of today's knowledge (Mainardes et al., 2010). Findings gathered from survey studies could help HEI identify areas for improvement in the curriculum and do appropriate actions. Hynes and Richardson (2007) (cited in Marinades et al., 2010) demonstrates in their study that HEIs need proper planning when they decide to develop a new university course. These courses should bring benefits for all: students, the job market, companies, government (in its pursue for revising and developing its national curriculum), society and for the HEI itself. The institution 
should be aligned with the interests of all the stakeholders involved in higher education (Mainardes et al., 2010). It is then the undertaking of this current study to assess its own graduates from batch 2010-2012, particularly of the Science and Mathematics Education Department, and to gain valuable insights if its curriculum and program offerings are preparing graduates for the field of work and eventually be hired and land a satisfying job.

\section{Conceptual Framework}

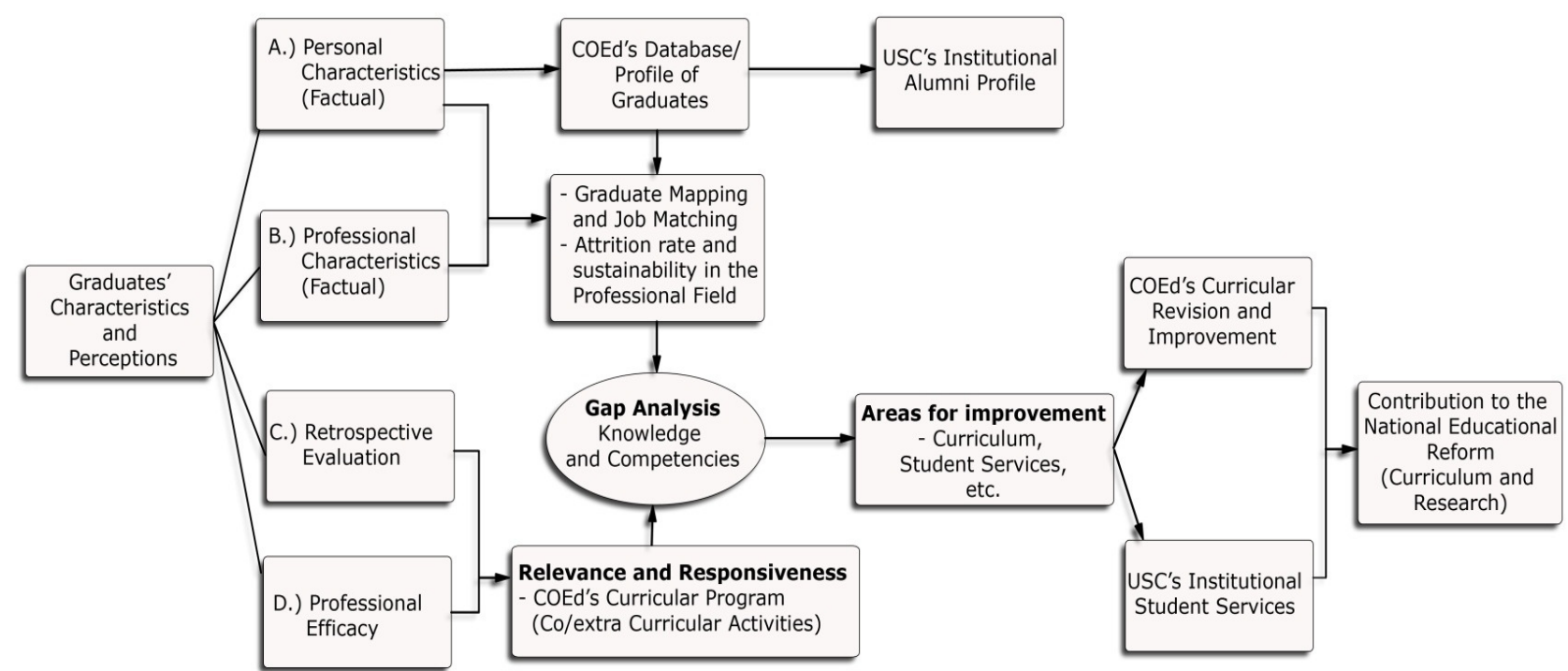

Figure 1. Conceptual Framework

In determining the relevance of USC COEd's curricular programs in meeting the needed manpower for regional and national development, an evaluation of its graduates' characteristics and perception are taken into consideration. These includes their a.) Personal Characteristics which are factual and includes their socio-demographic information, educational background, honors/awards while at USC, etc. b.) Professional Characteristics which are also factual and includes the professional exams they have taken and passed, further studies and trainings they have undergone, professional awards received, positions held and employment status, and other qualifications; c.) Retrospective Evaluation of their curricular program and experience while at USC that includes their personal perception in terms of the relevance of USC's curricular programs (General Education courses, Professional Education courses, Field Study and Practicum Experience), their participation in co/extra-curricular activities, their involvement in Community Extension Services (CES) and their Guidance and Students services experience. Graduates are evaluating the role and contribution of USC to their professional development; d.) Professional Efficacy includes the graduates' perceptions in terms of attaining the competencies specified in the graduates' degree program, personal satisfaction on the graduates' job performance (knowledge, skills, character/values and services) and lastly on the graduates professional fulfillment and satisfaction.

Probing the graduates personal characteristics will contribute in expanding both COEd and USC's database of its alumni's profile. Likewise, together with the information gathered in terms of their professional characteristics, proper mapping of the graduates in terms of their job matching, attrition rates and sustainability in the professional field could significantly be done. On the other hand, to be able to assess the graduates' retrospective evaluation and their professional efficacy could reveal vital information in terms of the relevance and responsiveness of COEd's curricular programs that also includes the co/extra-curricular activities 
experienced by the graduates. And together with the information gathered on mapping the graduates, gap analysis in terms of knowledge and competencies could be done in finding areas for improvement (curriculum, student services, etc.). This would serve as the basis for a possible revision and improvement of COEd's curricular offerings and initiate a closer look and re-evaluation of USC's institutional students services program. Lastly, it is hoped for, that the analysis and results of this research study could contribute to the national educational reform both in curriculum and research.

\section{Research Methods}

This current research activity on tracing USC COEd's Science and Mathematics Education graduates used the cross-sectional retrospective survey design. It was a design that investigates the graduates' experiences in USC that had occurred in the past. It aimed at finding out the prevalence of a phenomenon, problem, attitude or issue by taking a snap-shot or cross-section of the entire USC COEd's Science and Mathematics Education graduates' population. It had obtained an overall picture as it stands at the time of the study. This research was conducted at the University of San Carlos, Science and Mathematics Education Department (USC SMED) located in Talamban, Cebu City, Philippines. USC is a private Catholic university administered by the Society of the Divine Word (Societas Verbi Divini, SVD). SMED is a department under the College of Education (COEd) which was considered as Center of Excellence by the Commission on Higher Education (CHED).

The research respondents were the Science and Mathematics Education (SME) graduates who graduated from March 2010 to March 2012 with the following academic programs; Bachelor of Secondary Education major in Mathematics (BSEd Math), Bachelor of Secondary Education major in Physics and Chemistry (BSEd Physics-Chemistry), Bachelor of Secondary Education major in Physics and Mathematics (BSEd Physics-Math) and Bachelor of Secondary Education major in Biology and Chemistry (BSEd Biology-Chemistry). These graduates were exclusively recruited to the curricular program due to the extensive promotion and availability of scholarships and they were among the top high school graduates (Berg, 2012). In each batch there were valedictorians and salutatorians and other honor students. This made for a unique student population. Table 1 shows the breakdown of these graduates.

\section{Table 1}

SMED Graduate's Profile from Year 2010-2012

\begin{tabular}{|c|c|c|c|c|c|c|c|}
\hline SMED Program & $\begin{array}{c}\text { March } \\
2010\end{array}$ & $\begin{array}{c}\text { October } \\
2010\end{array}$ & $\begin{array}{c}\text { March } \\
2011\end{array}$ & $\begin{array}{c}\text { October } \\
2011\end{array}$ & $\begin{array}{l}\text { March } \\
2012\end{array}$ & $\begin{array}{c}\text { October } \\
2012\end{array}$ & Total \\
\hline BSEd Math & 1 & 0 & 1 & 0 & 1 & 2 & 5 \\
\hline BSEd Physics-Chemistry & 5 & 2 & 5 & 0 & 3 & 0 & 15 \\
\hline BSEd Physics-Math & 22 & 4 & 11 & 0 & 7 & 1 & 45 \\
\hline BSEd Biology-Chemistry & 0 & 0 & 0 & 0 & 0 & 0 & 0 \\
\hline Total & 28 & 6 & 17 & 0 & 11 & 3 & 65 \\
\hline
\end{tabular}

There were 65 SME graduates who graduated from March 2010 to March 2012. All of them were targeted to be given survey questionnaires which was constructed and prepared by the research team both in print and electronic format. This research instrument had undergone scrutiny and verification among expert professors, the guidance counselor, department chairs, and the college dean to validate if it truly measured what it intended to measure and how truthful the results were based from the established conceptual framework of the study. Several items were deleted, changed or rephrased based from the suggestions of the critiques but some items deleted were brought back because some of the faculty experts and the research team find it deemed essential to be included in the final survey instrument. To test the reliability of the questionnaire, a pilot testing was done with some older batches of the Science and Mathematics Education Alumni not within the targeted respondents. Those who had participated had graduated way back around the year 2003-2009 and were actually taking up master's degree in the department that is why it was easy for the researcher to contact and ask them to answer the survey questionnaire. 
The pilot testing was done to determine how long it took for the graduates to answer it, were the directions in it clear, were all items understood and if there were problems they had encountered answering the instruments. Feedback from these older alumni indicates that there were items in the instrument not applicable to them because they were not able to experience these activities way back when they were still undergraduate students particularly on the co-curricular activities. It was understandable because some of these student activities were just recently applied starting from the batch 2010 and it was okay if the older alumni did not answer these items. Overall, the pilot testing had successfully established the survey questionnaire to be reliable by having the older alumni as the inter-rater of the items and their assessments somehow agrees to that of the actual research respondents.

The survey yielded a response rate of $66.2 \%$ or 43 out of the 65 targeted respondents. Some of the graduates were working outside Cebu and were hard to reach that reduced the response rate and so electronic version of the survey questionnaires was sent thru their e-mails and/or Facebook accounts. Still few of them responded positively with the request. Data was processed, organized and analyzed using a Statistical Package for Social Sciences (SPSS, version 21). Descriptive statistics was used to summarize and organize data in frequency and percent distribution tables and cross tabulations of the variables. For quantitative continuous variables such as age and responses to rating scales, numerical summary measures such as the means and standard deviations were used. Paired t-test (two-tailed) was used to analyze the differences of the frequency and the impact of the work done by the practice teaching mentor and supervisor to the graduates during their practice teaching experience.

\section{Results and Discussions}

\subsection{Personal Characteristics of the SMED Graduates}

Table 2 shows the socio-demographic profile of the SMED graduates. Among the 43 respondents of the study, $26(60.5 \%)$ were female and $17(39.5 \%)$ were males. Only one got married and 97.0\% were single and still within the age range of 20 to 24 (90.7\%). With a minimum wage of P 10,200 per month for Class A cities in Cebu (DOLE Region VII-Cebu), 12 (27.9\%) of the graduates' parents had an income below P 5,000 and 13 $(30.2 \%)$ is between P 5,000 and P 10,000. Combining the two categories yielded a percentage of $58.1 \%(25$ out of 43) graduates with parents earning monthly income below the minimum wage. However, 24 (96.0\%) of these graduates had received scholarship grant mostly government sponsored as shown in the cross tabulation in Table 3. Furthermore, the table shows that 42 (97.7\%) of the SMED graduates had enjoyed scholarship grants either academic $(n=1)$, non-academic $(n=1)$, alumni sponsored $(n=1)$ or government sponsored $(n=39)$ to help support them financially in their studies.

Table 2

Socio-Demographic Profile of Graduates

\begin{tabular}{llrr}
\hline Characteristics & Number & Percentage \\
\hline Age, years & $20-24$ & 39 & $90.7 \%$ \\
& $25-29$ & 4 & $9.3 \%$ \\
\hline Gender & Female & 26 & $60.5 \%$ \\
& Male & 17 & $39.5 \%$ \\
\hline Civil Status & Single & 42 & $97.7 \%$ \\
& Married & 1 & $2.3 \%$ \\
\hline Estimated Income of Parents & less than P5000 & 12 & $27.9 \%$ \\
& P5000-P10,000 & 13 & $30.2 \%$ \\
& P10,000-P15,000 & 6 & $14.0 \%$ \\
& P15,000-P20,000 & 7 & $16.3 \%$ \\
& P20,000-P30,000 & 4 & $9.3 \%$ \\
& More than P30,000 & 1 & $2.3 \%$ \\
\hline
\end{tabular}


Tracing University of San Carlos' science and mathematics education graduates

Table 3

Monthly Income of Parents vs. Scholarship Grant Received

\begin{tabular}{|c|c|c|c|c|c|c|c|}
\hline \multicolumn{8}{|c|}{ Scholarship Grant Received } \\
\hline & & Academic & Non-academic & $\begin{array}{c}\text { Alumni } \\
\text { sponsored }\end{array}$ & $\begin{array}{c}\text { Govt. } \\
\text { sponsored }\end{array}$ & Total & Percentage \\
\hline \multirow{7}{*}{$\begin{array}{l}\text { Monthly } \\
\text { Income of } \\
\text { Parents }\end{array}$} & Less than $5 \mathrm{k}$ & 0 & 0 & 0 & 11 & 11 & $25.6 \%$ \\
\hline & $5 \mathrm{k}-10 \mathrm{k}$ & 1 & 1 & 0 & 11 & 13 & $30.2 \%$ \\
\hline & $10 \mathrm{k}-15 \mathrm{k}$ & 0 & 0 & 0 & 6 & 6 & $14.0 \%$ \\
\hline & $15-20 \mathrm{k}$ & 0 & 0 & 0 & 7 & 7 & $16.3 \%$ \\
\hline & $20 \mathrm{k}-30 \mathrm{k}$ & 0 & 0 & 1 & 3 & 4 & $9.3 \%$ \\
\hline & 30k-up & 0 & 0 & 0 & 1 & 1 & $2.3 \%$ \\
\hline & Total & 1 & 1 & 1 & 39 & 42 & $97.7 \%$ \\
\hline
\end{tabular}

As Table 4 indicates, only $4(9.3 \%)$ of the SMED graduates came from a private high school whereas 39 (90.7\%) came from the public high schools. 13 (30.2\%) of these graduates were from Mandaue Science High School which is a science-oriented school. Of the 43 respondents, 32 (74.4\%) finished their college degree with a specialization in Physics-Mathematics which is a common choice among SMED graduates. 19 (44.2\%) had graduated as Cum Laude and $5(11.6 \%)$ had graduated as Magna Cum Laude which shows the quality of the SMED graduates. The breakdown for each batch representation for this study were as follows; batch $2010(n=20$, $46.5 \%)$, batch $2011(\mathrm{n}=12,27.9 \%)$ and batch $2012(\mathrm{n}=11,25.6 \%)$, of which $39(90.7 \%)$ are government sponsored scholars.

\section{Table 4}

Educational Background of Graduates

\begin{tabular}{llrr}
\hline \multicolumn{1}{c}{ Characteristics } & & Number & Percentage \\
\hline High School Graduated from & Mandaue Science High School* & 13 & $30.2 \%$ \\
& Mandaue Comprehensive HS* & $4.3 \%$ \\
& Pit-os National High School* & 3 & $7.0 \%$ \\
& San Remegio National HS* & 3 & $4.7 \%$ \\
& Others public & 2 & $39.5 \%$ \\
& Others private & 17 & $9.3 \%$ \\
\hline College Degree Earned & BSEd & 4 & $100.0 \%$ \\
\hline Specialization & BSEd-Mathematics & 43 & $4.7 \%$ \\
& BSEd-Physics-Math & 2 & $74.4 \%$ \\
& BSEd-Physics-Chemistry & 32 & $20.9 \%$ \\
\hline Year Graduated & March 2010 & 9 & $44.2 \%$ \\
& October 2010 & 19 & $2.3 \%$ \\
& March 2011 & 1 & $27.9 \%$ \\
& October 2011 & 12 & $0.0 \%$ \\
& March 2012 & 0 & $25.6 \%$ \\
& October 2012 & 11 & $0.0 \%$ \\
\hline Honors/Awards Received & Magna Cum Laude & 0 & $11.6 \%$ \\
& Cum Laude & 5 & $44.2 \%$ \\
\hline Scholarship grant received & Academic & 19 & $2.3 \%$ \\
& Non-academic & 1 & $2.3 \%$ \\
& Alumni Sponsored & 1 & $2.3 \%$ \\
& Govt. Sponsored & 1 & $90.7 \%$ \\
& Missing & 39 & $2.3 \%$ \\
\hline
\end{tabular}

Note: Schools with the asterisk symbol (*) are Public High School

\subsection{Professional Characteristics of the SMED Graduates}

Table 5 shows the professional characteristic of the SMED graduates. Of the 43 respondents, $39(90.7 \%)$ had taken and passed the Licensure Exam for Teachers (LET) in their first take of the exam. Their mean LET grade 
was $82.5(\mathrm{~N}=31)$ with a standard deviation of \pm 2.4 that indicates a passing range from 80.1 to 84.9 which is above the LET passing percentage of 75. Two of them were topnotchers, one was top 8 in the December 2011 board exam and the other one was ranked top 10 in the December 2012 board exam. One was awarded as the World's Best oral Research Presenter during the August 2012 World Research Festival. 18 (41.8\%) had now pursued graduate studies and majority of them $(\mathrm{N}=12)$ had taken Master of Arts in Education major in Math, of which 5 had finished and graduated. At least 13 local seminars, 10 regional, 6 national and 14 international conferences being attended had been specified by the SMED graduates as their avenue for professional growth, updating, upgrading, professional development and a testimony for being life-long learners.

\section{Table 5}

Professional Characteristics of the Graduates

\begin{tabular}{|c|c|c|c|}
\hline Characteristics & & Number & Percentage \\
\hline \multicolumn{4}{|l|}{ Professional Exam passed } \\
\hline & LET & 39 & $90.7 \%$ \\
\hline & missing & 4 & $9.3 \%$ \\
\hline & $\mathrm{N}$ & Mean & Standard Deviation \\
\hline LET Exam Grade Result & $31 *=72.1 \%$ & 82.5 & 2.4 \\
\hline \multirow{4}{*}{ Professional Award } & & & Number \\
\hline & Top 8 LET December 2011 & \multicolumn{2}{|l|}{1} \\
\hline & Top 10 LET December 2012 & \multicolumn{2}{|l|}{1} \\
\hline & World's Best Oral Researcher & \multicolumn{2}{|l|}{1} \\
\hline Further Studies and Training & MAEd-Educational Management & 1 & $2.3 \%$ \\
\hline \multirow[t]{4}{*}{ Graduate Studies Pursued } & MAEd-Physics & 5 & $11.6 \%$ \\
\hline & MAEd-Math & 12 & $27.9 \%$ \\
\hline & \multicolumn{3}{|l|}{$($ graduated $=5 * *)$} \\
\hline & missing & 25 & $58.1 \%$ \\
\hline \multirow[t]{4}{*}{ Seminars Attended } & Local & 13 & \\
\hline & Regional & 10 & \\
\hline & National & 6 & \\
\hline & International & 14 & \\
\hline
\end{tabular}

As Table 6 indicates, out of the 43 respondents, 40 (93.0\%) were currently employed, to which 31 (72.1\%) were working in fulltime and in permanent status. $36(83.7 \%)$ were into teaching and looking at Table 6.1 for the cross tabulation between employment status and the type of institution employed with, 12 (27.9\%) were full-time permanent teacher in a private school while $22(51.2 \%)$ were full-time permanent teacher in the public school. It indicates that in just a short span of time, the SMED graduates were able to land a regular job. Further analysis in terms of cross tabulating between the year they had graduated versus the type of institution employed as shown in Table 6.2, revealed that for batch 2010, 15 out of the 20 employed respondents were now teaching in public schools, 7 of the 11 employed respondents in batch 2011 were now in the public schools and still only 1 out of 9 employed respondents of the 2012 batch had been absorbed in the public school system. It seems that once the SMED graduates had taken and passed their Licensure Exam, they opt out of their previous employment and migrated to the public school system where they can land a regular and permanent work.

Moreover, Table 6.3 on cross tabulation between their monthly gross income to the type of institution employed with, shows that monthly compensation offered in the public school can match the offer given in the private institution where 17 of the SMED graduates were receiving 10T to 20T, whereas 10 of the graduates are receiving the same amount in the private school. Public school's salary grade can even compete with that of the private schools where 6 of the graduates are receiving 30T to 40T with only 1 in the private institution. This indicates that greener pastures for the SMED graduates and a stable one here in the country would be to land a teaching post in the public school system. 
Table 6

Current Employment Status of the Graduates

\begin{tabular}{llrr}
\hline \multicolumn{1}{c}{ Characteristics } & & Number & Percentage \\
\hline Current employment & Employed & 40 & $93.0 \%$ \\
& Unemployed & 3 & $7.0 \%$ \\
If employed, what is the status? & Part-time & 1 & $2.3 \%$ \\
& Full-nonpermanent & 8 & $18.6 \%$ \\
& Full-permanent & 31 & $72.1 \%$ \\
Nature of current work & Teaching & 36 & $83.7 \%$ \\
& Non-Teaching & 4 & $9.3 \%$ \\
For those who are teaching, what type of & Private-secondary & 12 & $27.9 \%$ \\
institution are you employed with? & Public-secondary & 23 & $53.5 \%$ \\
& Private college/university & 1 & $2.3 \%$ \\
Current monthly gross income & Others & 4 & $9.3 \%$ \\
& Less than 10T & 1 & $2.3 \%$ \\
& 10T-20T & 31 & $72.1 \%$ \\
\hline
\end{tabular}

Table 6.1

Employment Status vs. Type of Institution Employed With

\begin{tabular}{llcccccc}
\hline & & \multicolumn{3}{c}{ Type of institution employed with } & & Total & Percentage \\
\cline { 3 - 6 } & & $\begin{array}{c}\text { Private-se } \\
\text { condary }\end{array}$ & $\begin{array}{c}\text { Public-sec } \\
\text { ondary }\end{array}$ & $\begin{array}{c}\text { Private } \\
\text { college/univ }\end{array}$ & Others & & \\
\hline \multirow{2}{*}{ Employment } & Part-time & 0 & 1 & 0 & 0 & 1 & $2.3 \%$ \\
& Full-nonpermanent & 6 & 0 & 1 & 1 & 8 & $18.6 \%$ \\
& Full-permanent & 6 & 22 & 0 & 3 & 31 & $72.1 \%$ \\
& Total & 12 & 23 & 1 & 4 & 40 & $93.0 \%$ \\
\hline
\end{tabular}

\section{Table 6.2}

Year Graduated vs. Type of Institution Employed With

\begin{tabular}{ccccccccc}
\hline & & \multicolumn{3}{c}{ Type of institution employed with } & & \multirow{2}{*}{ Total } & Percentage \\
\cline { 3 - 6 } & & $\begin{array}{c}\text { Private-se } \\
\text { condary }\end{array}$ & $\begin{array}{c}\text { Public-sec } \\
\text { ondary }\end{array}$ & $\begin{array}{c}\text { Private } \\
\text { college/univ }\end{array}$ & Others & & \\
\hline \multirow{5}{*}{ Year graduated } & March 2010 & 4 & 14 & 1 & 0 & 19 & $44.2 \%$ \\
& October 2010 & 0 & 1 & 0 & 0 & 1 & $2.3 \%$ \\
& March 2011 & 2 & 7 & 0 & 2 & 11 & $25.6 \%$ \\
& March 2012 & 6 & 1 & 0 & 2 & 9 & $20.9 \%$ \\
& Total & 12 & 23 & 1 & 4 & 40 & $93.0 \%$ \\
\hline
\end{tabular}

\section{Table 6.3}

Gross Monthly Income vs. Type of Institution Employed With

\begin{tabular}{|c|c|c|c|c|c|c|c|}
\hline & & \multicolumn{4}{|c|}{ Type of institution employed with } & \multirow[b]{2}{*}{ Total } & \multirow[b]{2}{*}{ Percentage } \\
\hline & & $\begin{array}{c}\text { Private-sec } \\
\text { ondary }\end{array}$ & $\begin{array}{l}\text { Public-sec } \\
\text { ondary }\end{array}$ & $\begin{array}{c}\text { private } \\
\text { college/univ }\end{array}$ & Others & & \\
\hline \multirow{4}{*}{$\begin{array}{l}\text { Current gross } \\
\text { monthly income }\end{array}$} & Less than $10 \mathrm{~T}$ & 1 & 0 & 0 & 0 & 1 & $2.3 \%$ \\
\hline & $10 \mathrm{~T}-20 \mathrm{~T}$ & 10 & 17 & 1 & 3 & 31 & $72.1 \%$ \\
\hline & $30 \mathrm{~T}-40 \mathrm{~T}$ & 1 & 6 & 0 & 1 & 8 & $18.6 \%$ \\
\hline & Total & 12 & 23 & 1 & 4 & 40 & $93.0 \%$ \\
\hline
\end{tabular}

\subsection{SMED Graduates' Retrospective Evaluation of their Curricular Program and Educational Experiences at USC}

Being able to assess the graduates' retrospective evaluation revealed vital information in terms of the 
relevance and responsiveness of COEd SMED's curricular programs including the co/extra-curricular activities experienced by the graduates. On Table 7, under the curriculum section, the SMED graduates were asked to evaluate in terms of the sequencing of subjects, quality of instruction and materials, teacher consultation, grading, research, field study and practicum. Overall, it has a mean value of 1.91 with a standard deviation of \pm 0.56 which has a mean interpretation of "very good". Generally, the SMED graduates were satisfied with their curriculum experience and their responses were not that varied as can be seen in the standard deviation. Particularly, they had rated the sequencing of their subjects well enough with a mean value of 1.79 , which is interpreted as "Excellent" and with a standard deviation of \pm 0.60 , which means that the ratings are close to each other. On the other hand, Field Study, OJT and practicum rated the lowest among the seven criteria with a mean value of 2.10 but their answers were a bit spread out and varied because it has as well the highest recorded standard deviation of \pm 0.93 .

\begin{tabular}{ll}
\hline & Mean interpretation \\
\hline $1.00-1.80$ & Excellent \\
$1.81-2.60$ & Very Good \\
$2.61-3.40$ & Good \\
$3.41-4.20$ & Fair \\
$4.21-5.00$ & Poor \\
\hline
\end{tabular}

Table 7

Graduates' Retrospective Evaluation-Relevance of USC's Curricular Program

\begin{tabular}{lccc}
\hline \multicolumn{1}{c}{ Curriculum } & Mean & $S D$ & Interpretation \\
\hline Sequence of subject & 1.79 & .60 & Excellent \\
Quality of instructional materials & 1.84 & .78 & Very Good \\
Assessment \& grading & 1.84 & .69 & Very Good \\
Quality of instruction & 1.91 & .61 & Very Good \\
Teacher consultation & 1.98 & .80 & Very Good \\
Participation in research & 2.00 & .72 & Very Good \\
Field Study, OJT \& practicum & 2.10 & .93 & Very Good \\
Overall & 1.91 & .56 & Interpretation \\
\hline \multicolumn{1}{c}{ Student activities } & Mean & $S D$ & Very Good \\
\hline Curricular activities & 1.98 & .80 & Very Good \\
Co-Curricular activities & 2.19 & .76 & Gery Good \\
Community extension & 2.35 & .75 & Geod Good \\
Extra-curricular activities & 2.74 & .76 & Interpretation \\
\hline Student services & 2.31 & .61 & Very Good \\
\hline Library services & Mean & $S D$ & Very Good \\
Computer \& internet services & 2.05 & .90 & Very Good \\
Medical, dental and guidance & 2.47 & 1.03 & Very Good \\
\hline
\end{tabular}

Still on table 7, this time on the student activities section, curricular activities which were subject related activities done outside the classroom, rated the highest with a mean score of 1.98 (interpreted as "very good") and a standard deviation of \pm 0.80 . This finding shows that apart from the rigorous emphasis on basic concepts, the promotion of "fun" science and mathematics through discrepant events like science exhibition and demonstration, science theatre, and science competitions (Berg, 2012) in the curriculum proved to be effective to the graduates. Extra-curricular activities on the other hand, that involved activities organized by other organization outside of the university, ranked the lowest in this section with a mean and standard deviation value of $2.74 \pm 0.76$ with the interpretation of "good". This is because participation to these activities is a student's prerogative and initiative and it is not necessarily a university, college or department regulated or supervised activity. Lastly, on the section on student services, which ranked the lowest section in this category, has an overall mean score of 2.36 with a standard deviation of \pm 0.85 . It seems that the graduates are not that 
particularly satisfied with the university support services, more specifically on the medical, dental and guidance services which ranked the lowest here with a mean value of 2.58. It does not mean though that the university is not providing these services as it is still rated "very good" overall by the graduates but the services are just not significantly felt by the respondents.

Moving on, table 8 below shows how the graduates evaluated their curricular program in developing their knowledge, skills and competencies important in the field of teaching. Five criteria emerged excellent here, namely from highest to lowest; $1^{\text {st }}-$ Content Specialization Knowledge $(1.47 \pm 0.55), 2^{\text {nd }}-$ Critical thinking skills $(1.53 \pm 0.59), 3^{\text {rd }}-$ Numeracy skills $(1.58 \pm 0.54), 4^{\text {th }}-$ Problem solving skills $(1.63 \pm 0.66)$ and $5^{\text {th }}-$ Literacy skills $(1.74 \pm 0.62)$. These findings shows that SMED had significantly developed its graduates in terms of these essential attributes to become an effective science and math teachers particularly in terms of problem solving skills, critical thinking, numeracy and most especially the content specialization. Rohaan et al. (2012) and Yilmaz-Tuzun (2008) both showed the importance of content specialization for increasing the competence and self-efficacy of teachers in teaching science. As what Bandura (1997) and (Tschannen-Moran \& Woolfolk, 2007) (mentioned in Velthuis et al., 2014) suggested that teachers with a high sense of self-efficacy for teaching will set higher goals, more confident in his/her delivery, and are resourceful enough in finding strategies to teach effectively to his/her students.

Ranked at the bottom in this category were criteria on reflective thinking and understanding of the learning process which both has a mean score of 1.09 with a standard deviation of \pm 0.57 and \pm 0.61 respectively. Content specialization is important in developing future science and math teachers but it is equally important that the graduates have to be knowledgeable as well in terms of how the learning process of the students' works, the "hows" of teaching (pedagogical knowledge) should also be emphasized. Significantly, it is ranked the lowest here. The findings showed that the curriculum did not put much work and emphasis in this area as compared to the first in rank but it is worth to mention that to be really an effective and competent teacher, superior content knowledge (CK) is not enough, it has to be complemented with the mastery of the pedagogy, what is known as pedagogical-content knowledge (PCK). This knowledge is highlighted by knowing what teaching approaches fit the content, and likewise, knowing how content element can be arranged and re-arranged for better teaching. PCK is defined as the knowledge base necessary to transform subject matter knowledge into forms comprehensible to the students (Jüttner, 2013).

\section{Table 8}

Knowledge, skills and competencies being developed by the graduates

\begin{tabular}{|c|c|c|c|}
\hline Knowledge, skills and competencies & Mean & $S D$ & Interpretation \\
\hline Content specialization knowledge & 1.47 & .55 & Excellent \\
\hline Critical thinking skills & 1.53 & .59 & Excellent \\
\hline Numeracy skills & 1.58 & .54 & Excellent \\
\hline Problem-solving skills & 1.63 & .66 & Excellent \\
\hline Literacy skills & 1.74 & .62 & Excellent \\
\hline IT skills for teaching & 1.86 & .68 & Very Good \\
\hline Oral communication skills & 1.93 & .55 & Very Good \\
\hline General education knowledge & 1.95 & .62 & Very Good \\
\hline Written communication skills & 1.95 & .58 & Very Good \\
\hline Systematic planning and organization & 1.98 & .74 & Very Good \\
\hline Teaching process skills & 1.98 & .71 & Very Good \\
\hline Professional education knowledge & 2.02 & .71 & Very Good \\
\hline Field study and practicum knowledge & 2.07 & .77 & Very Good \\
\hline Reflective thinking & 2.09 & .57 & Very Good \\
\hline Understanding of the learning process & 2.09 & .61 & Very Good \\
\hline Overall & 1.86 & .46 & Very Good \\
\hline
\end{tabular}

\subsection{SMED Graduates' Retrospective Evaluation of their experiences working with their Practice Teaching Mentor and Supervisor}


Here in this section, it tried to describe as to what extent did the work of the practice teaching (PT) mentor and supervisor had influenced and improved the teaching skills and knowledge of the graduates in terms of the essential aspects in the teaching profession. PT mentor here refers to the teacher from the affiliated school, handling the class that the practice teacher will be assigned to teach. Usually, 2 practice teachers are assigned to a PT mentor. While the PT supervisor here, refers to the SMED faculty handling the on the job training (OJT) of the graduates. Table 9 and 10 illustrates the frequency of the help and assistance of the PT mentor and supervisor in terms of the following aspects; teaching of the subject matter, classroom management, using instructional methods, using technology in the classroom, assessing students and interpreting data, selecting instructional material and writing lesson plans, interacting with parents and reflecting on their teaching practice.

\section{Table 9}

Experiences with the Practice Teaching Mentor

\begin{tabular}{|c|c|c|c|}
\hline Frequency of working the following areas & Mean & $S D$ & Interpretation \\
\hline Classroom management & 3.47 & .83 & At least once a week \\
\hline Adapting curriculum \& writing lesson plan & 3.44 & .88 & At least once a week \\
\hline Teaching subject matter & 3.44 & .83 & At least once a week \\
\hline Reflecting on teaching practice & 3.30 & .91 & At least once a week \\
\hline Instructional methods & 3.23 & .97 & Once or Twice a Month \\
\hline Assessing students & 3.16 & 1.09 & Once or Twice a Month \\
\hline Using technology in the classroom & 2.93 & .99 & Once or Twice a Month \\
\hline Interacting with parents & 2.05 & 1.19 & A Few times in a Semester \\
\hline Overall & 3.13 & .77 & Once or Twice a Month \\
\hline
\end{tabular}

\section{Table 10}

Experience with the Practice Teaching Supervisor

\begin{tabular}{|c|c|c|c|}
\hline Frequency of working the following areas & Mean & $S D$ & Interpretation \\
\hline Reflecting on teaching practice & 3.33 & .81 & At least once a week \\
\hline Using technology in the classroom & 3.23 & .78 & Once or Twice a Month \\
\hline Instructional methods & 3.16 & .75 & Once or Twice a Month \\
\hline Teaching subject matter & 3.12 & .82 & Once or Twice a Month \\
\hline Adapting curriculum \& writing lesson plan & 3.07 & .91 & Once or Twice a Month \\
\hline Classroom management & 3.05 & .82 & Once or Twice a Month \\
\hline Assessing students & 2.98 & .86 & Once or Twice a Month \\
\hline Interacting with parents & 2.05 & 1.15 & A Few times in a Semester \\
\hline Overall & 3.00 & .70 & Once or Twice a Month \\
\hline
\end{tabular}

Similarly, both PT mentor and supervisor worked the least in terms of how the practice teacher should interact with the parents. The mean and standard deviation score in this area for the PT mentor was $2.05 \pm 1.19$ while for the PT supervisor was $2.05 \pm 1.15$. It had a mean interpretation of "a few times in a semester". This is for the fact that in the secondary level (high school), teachers do not have regular contact or meeting with the parents as high school students are more mature and independent with their studies. Unlike in the pre-elementary and elementary level where parents are very much hands on in monitoring their children's performance at school and frequently has to ask and consult teachers in case there are concerns they have with the school performance of their child.

The highest rated area being worked and focused on by the PT mentor, based from the graduates' retrospective evaluation, was more on classroom management with a mean and standard deviation value of 3.47 \pm 0.83 , still interpreted as "at least once a week". Basically this result was expected since, on the field, one major concern of a beginning teacher is how to handle and manage the class well, since high school students seemed to be testing the patience of the practice teacher and because their age gap is very close. Practice teacher's usually ranged from 19-21 years of age while for the $4^{\text {th }}$ year high school students, their age ranges from 15-17 years old. With these, authority and being in control of the class is very challenging for the practice teacher. In relations to that, Leatham and Peterson (2010) mentioned in their study when they surveyed practice teaching mentors, that 
classroom management was seen by the CT as one of the primary purpose of student teaching. Classroom discipline in terms of how to manage student's behavior was specifically mention by the CT in their research.

On the other hand, the highest rated area being worked and focused on by the PT supervisor was on reflecting their teaching practice with a mean and standard deviation value of $3.33 \pm 0.81$, interpreted as "at least once a week". This is significantly true since usually the PT supervisor meets with the practice teachers on a weekly basis to do sharing and discussion of their teaching experiences.

To further analyze this category, a two tailed, paired t-test using SPSS v.21 was conducted to find out if there was significant difference between the two overall means in terms of frequency of work between the CT mentor and supervisor based from the retrospective evaluation of the graduates. Table 11 and 12 shows the paired t-test statistics and differences respectively.

\section{Table 11}

Paired t-test Statistics for Frequency of Mentor and Supervisor's Work with the Student Teacher

\begin{tabular}{|c|c|c|c|c|c|}
\hline & & Mean & $N$ & $S D$ & Std. Error Mean \\
\hline \multirow{2}{*}{ Pair 1} & $\begin{array}{l}\text { Overall Frequency of } \\
\text { Practice Teaching Mentor's } \\
\text { work with the Student } \\
\text { Teacher }\end{array}$ & 3.1279 & 43 & .76692 & .11695 \\
\hline & $\begin{array}{l}\text { Overall Frequency of } \\
\text { Practice Teaching } \\
\text { Supervisor's work with the } \\
\text { Student Teacher }\end{array}$ & 2.9971 & 43 & .70102 & .10691 \\
\hline
\end{tabular}

\section{Table 12}

Paired t-test Difference for Frequency of Mentor and Supervisor's Work with the Student Teacher

\begin{tabular}{|c|c|c|c|c|c|c|c|c|c|}
\hline & & \multicolumn{5}{|c|}{ Paired Differences } & \multirow{3}{*}{$t$} & \multirow{3}{*}{$d f$} & \multirow{3}{*}{$\begin{array}{c}\text { Sig. } \\
\text { (2-tailed) }\end{array}$} \\
\hline & & \multirow[t]{2}{*}{ Mean } & \multirow[t]{2}{*}{$S D$} & \multirow[t]{2}{*}{$\begin{array}{l}\text { Std. } \\
\text { Error } \\
\text { Mean }\end{array}$} & $\begin{array}{l}95 \% \quad \mathrm{Cc} \\
\text { Interval } \\
\text { Difference }\end{array}$ & $\begin{array}{l}\text { Confidence } \\
1 \text { of the } \\
\text { nce }\end{array}$ & & & \\
\hline & & & & & Lower & Upper & & & \\
\hline Pair 1 & $\begin{array}{l}\text { Overall frequency of } \\
\text { practice teaching } \\
\text { mentor's work with } \\
\text { the student teacher } \\
\quad \text { vs. } \\
\text { Overall frequency of } \\
\text { practice teaching } \\
\text { supervisor's work } \\
\text { with the student } \\
\text { Teacher }\end{array}$ & .13081 & .57861 & .08824 & -.04726 & .30888 & 1.483 & 42 & .146 \\
\hline
\end{tabular}

Looking at table 11 and 12 as the SMED graduates $(\mathrm{N}=43)$ evaluates the frequency of work done by the PT mentor and supervisor during their practice teaching experience, the $t$ test failed to reveal a statistically reliable difference between the overall mean of the PT mentor $(\mathrm{M}=3.1279, \mathrm{SD}=0.76692)$ and that of the PT supervisor $(\mathrm{M}=2.9971, \mathrm{SD}=0.70102), t(42)=1.483, p>0.05$. Therefore, there was not enough evidence available to suggest that there was a difference between the overall mean of PT mentor and supervisor at the $95 \%$ confidence level.

\subsection{Graduates' Assessment of their Professional Efficacy to Achieve their Career Goals}

Being able to gauge the professional efficacy of the SMED graduates, gives significant insights in improving the USC's institutional academic and career guidance program, student services and community extension services. These includes their perceptions in terms of attaining the competencies specified in their 
degree program, personal satisfaction on their job performance (knowledge, skills, character/values and services) and lastly on their professional fulfilment and satisfaction. Table 13 specifically looks into this skills and attitudes being developed by the graduates in their stay with the college and with the department and how they assess themselves in terms of the essentiality of these character traits for professional efficacy in their line of work.

The overall mean in this category is 1.93 with a standard deviation of \pm 0.46 that indicates a mean interpretation of "very essential". This means that in general, the college and the department are able to essentially impart these character traits necessary for the graduates in their current jobs. Particularly the highest in rank and is deemed "extremely essential" was working with people with different background, with a mean value of $1.75 \pm 0.63$, working with others towards common goal $(1.78 \pm 0.66)$ was the second and valuing the individual contribution of members $(1.80 \pm 0.72)$ was the third. It seems that majority of the top character traits developed in the graduates in order for them to be professionally effective has something to do with working with others, building a good team relationship and establishing team work. On the contrary, the three character traits that ranked lowest at the bottom has to do with self-coping up mechanism that includes; dealing with disappointments $(2.28 \pm 0.78)$, assuming leadership roles $(2.10 \pm 0.78)$ and controlling emotions $(2.08 \pm 0.62)$.

\begin{tabular}{ll}
\hline & Mean Interpretation \\
\hline $1.00-1.80$ & Extremely Essential \\
$1.81-2.60$ & Very Essential \\
$2.61-3.40$ & Moderately Essential \\
$3.41-4.20$ & Slightly Essential \\
$4.21-5.00$ & Not at All \\
\hline
\end{tabular}

Table 13

Graduate's Assessment of Their Skills and Attitude Being Developed - Essential in Their Work

\begin{tabular}{|c|c|c|c|c|}
\hline Skills and attitude & & Mean & $S D$ & Interpretation \\
\hline Working with people of different background & & 1.75 & .63 & Extremely Essential \\
\hline Working with others towards common goal & & 1.78 & .66 & Extremely Essential \\
\hline Valuing the individual contribution of members & & 1.80 & .72 & Extremely Essential \\
\hline Establishing positive work relationship & & 1.83 & .64 & Very Essential \\
\hline Motivating self towards goal & & 1.83 & .50 & Very Essential \\
\hline Confidence in self & & 1.88 & .56 & Very Essential \\
\hline Contribute to learning at workplace & & 1.90 & .74 & Very Essential \\
\hline Exercising initiative and creativity & & 1.90 & .71 & Very Essential \\
\hline Adaptability with change & & 1.93 & .66 & Very Essential \\
\hline Communication skills (effective listening) & & 1.93 & .53 & Very Essential \\
\hline Working with people of diff. background & & 1.93 & .66 & Very Essential \\
\hline Communication skills (expressing opinions) & & 1.95 & .64 & Very Essential \\
\hline Taking initiative in professional development & & 1.98 & .70 & Very Essential \\
\hline Staying composed in dealing with pressure & & 2.00 & .64 & Very Essential \\
\hline Exercising self-control & & 2.00 & .55 & Very Essential \\
\hline Controlling emotions & & 2.08 & .62 & Very Essential \\
\hline Assuming leadership roles & & 2.10 & .78 & Very Essential \\
\hline \multirow[t]{2}{*}{ Dealing with disappointments } & & 2.28 & .78 & Very Essential \\
\hline & Overall & 1.93 & .46 & Very Essential \\
\hline
\end{tabular}

\subsection{Significance and implication of the study}

Graduate tracer studies (GTS) are important to Higher Education Institutions since it enabled such institutions to accommodate changes in the society especially the demands of the actual and potential employers, through evaluation and constant review of their curricula. The use of GTS is an appropriate tool in determining institutional capability in preparing graduates to meet the demands of the workplace. The insights gathered from 
Tracing University of San Carlos' science and mathematics education graduates

this current research study are significant and implies the following aspects:

$>\quad$ Analysis and results of this research study could contribute to the national educational reform agenda both in curriculum and research.

$>\quad$ School administrators may benefit from the findings by instituting curricular reforms facilitating their students' transition from the academe to the world of work.

$>\quad$ Probing the graduates' personal characteristics will contribute in expanding both COEd's and USC's database of its alumni's profile.

$>$ Study results can be used in improving the USC's institutional academic and career guidance program, student services and community extension services.

$>$ Prospective USC students shall have a basis for curricular choice and career preparation.

$>\quad$ And eventually, for a possible curricular revision that the college will initiate, actual and potential employers will be assured that future job seeking teacher candidates from USC are employable graduates and that they understand their professional responsibility and are positive in their thinking.

\section{Conclusions and Recommendations}

\subsection{Conclusions}

The use of a graduate tracer study (GTS) was an appropriate tool in profiling the graduates and determining the institutional capability of SMED and the relevance of its curricular programs in preparing graduates to meet the demands of the workplace. Out of SMED's 65 graduates that graduated from the year 2010 to 2012,43 $(66.2 \%)$ had responded to this research endeavor. Majority of them had parents earning a monthly income below the minimum wage. However, a high percentage of these graduates were government scholars who mostly came from public high schools. The Board exam results of these graduates were seemingly very impressive with a very high passing percentage for first time takers and having a mean LET grade of $82.5 \pm 2.4$. In addition, two graduates were board exam topnotchers. This just showed the quality of these graduates being produced.

Being lifelong learners can be attributed to these graduates since a couple of them had pursued master's degree as early as after graduation and 5 had already completed and finished their graduate studies. They were continually attending seminars and conferences not only locally and regionally but also national and even in international settings.

Employability was also very promising for this group wherein majority were able to land a regular and permanent employment in just a short span of time, more particularly a teaching job in a secondary public high school. It seems that once these SMED graduates had taken and passed their Licensure Exam, they opt out of their previous employment and migrated to the public school system where they can land a regular and permanent work. Monthly compensation in the public schools is not that discrepant anymore with the private institution unlike before and it can already match the salary grade offered by the private schools.

Sequencing of the subjects in the curriculum was rated as the highest by these graduates while knowledge and skills like, Content Specialization, Critical thinking skills, Numeracy skills, Problem solving skills and Literacy skills were seen to have been well-developed among the graduates during their stay in the university. Extra-curricular activity involvement organized by outside the university organization is among the least ranked as it was not given much priority in their curriculum. This is because participation to these activities was student's prerogative and initiative and it is not necessarily a university, college or department regulated or supervised activity. 
Furthermore, majority of the top rated character traits for professional efficacy being developed during their stay with the university has something to do with working with others, building a good team relationship and establishing team work. On the contrary, the three character traits that ranked lowest at the bottom had something to do with self-coping up mechanism like dealing with disappointments, assuming leadership roles and controlling emotions.

Although the study found evidences of institutional capability of SMED and the relevance of its curricular programs thru tracing its graduates, a future supplementary research has to be undertaken in getting feedback and points of view from the employers perspective in order to support these findings and gain valuable insights as to how are the SMED graduates performing in their schools or institutions.

\subsection{Recommendations}

The following recommendations were made taking into consideration the results obtained in this study as well as the current educational reform experienced in the university in particular and in the country in general.

A. Extensive promotional activity to attract brilliant students to go into science and mathematics teaching should be a regular activity of the department in order to have a continuous pool of gifted and creative students. Particularly targeting those who have passed and availed government sponsored scholarships like Department of Science and Technology (DOST) or CHED.

B. Update the current curriculum to be K-12 ready foreseeing that the future SMED graduates should be equipped with the tools, knowledge, skills and attitude needed to teach confidently the students of the $\mathrm{K}-12$ system during its full implementation.

C. Align the curricular and co-curricular activities in developing a true Carolinian Teacher imbued with the core values as specified in the institutional OBE (Outcomes Based Education) of Scientia, Virtus and Devotio.

D. Plan, lay-out and execute a guidance center intervention program that will help graduates develop both personal (self) and group (team) character traits that would be deemed essential in their future careers.

E. Community Extension Services should be given equal priority as a student activity while in college as it is one of the core functions of the university.

F. To have a possible benchmarking of courses offered by the neighboring ASEAN countries in order to be globally competent and relevant especially that the country will open its borders to the ASEAN member countries by 2015 .

G. The curricula should reflect and remain responsive to the changes taking place in the information world, the application of ICT to information handling, training and teaching in the 21 st century.

H. Develop a more functional framework for employability that involves the identification of the graduates' learning outcomes aligned with the institution's vision, mission and goals. One that is consistent with the skills needed by the employer, the use of appropriate and innovative activities for teaching and learning, and a systematic use of student to mentor/supervisor (vice versa) feedback scenario that is grounded in a sound evaluation and reflection processes. 
Tracing University of San Carlos' science and mathematics education graduates

Acknowledgements - This research endeavour was made possible through the deloading support afforded to the researcher from the Science and Mathematics Education Department and University of San Carlos' Office of Research, for that I am most grateful and privileged. The researcher would like to thank our COEd Research Committee Chair, Dr. Enriqueta D. Reston for spearheading and continuously guiding the researcher and the Graduate Tracer Study (GTS) research team represented by Dr. Cristie Ann Delfin of the Department of Teacher Education, Mr. Marino Garcia and Mrs. Astrid Ocampo of the Department of Physical Education and Mrs. Ruvilyn Aguejetas of the Home Technology Section; particularly, more on Dr. Reston's sharing of her research and statistical expertise that indeed contributed positively in the conduct of this tracer study and the analysis/interpretation of the data. Likewise, a sincere gratitude to the aforementioned GTS research team for their invaluable support, encouragement and advises for the study to be successful. A million thanks as well for the unwavering moral, emotional and financial support of the researcher's family and above all, utmost appreciation to the Almighty God for the divine guidance and intervention in this research activity. With that, I remain. Thank you.

Monell John F. Cañizares

The researcher"

\section{References}

Aina, L. O., \& Moahi, K. (1999). Tracer study of the Botswana library school graduates. Education for Information, 17, 215-244.

Bandura, A. (1997). Self-efficacy: The exercise of control, New York: Freeman.

Belfield, C. R., Bullock, A. D., \& Fielding, A. (1999). Graduates' views on the contribution of their higher education to their general development: A retrospective evaluation for the United Kingdom. Research in Higher Education, 40(4), 409-438. http://dx.doi.org/10.1023/A:1018736125097

Berg, E. van den (2012). Long term effects of an innovative physics teacher education program in the Philippines. In A. Lindell, A. L. Kähkönen, \& J. Viiri (Eds.), Physics Alive. Proceedings of the GIREP-EPEC 2011 Conference (pp. 149-154).

De Guzman, A. B., \& De Castro, B. V. (2008). Employment and employability profile of a select group of Filipino college graduates. KEDI Journal of Educational Policy, 5(1), 63-81.

Ingersoll, R., Merrill, L., \& May, H. (2012). Retaining teachers: How preparation matters. Educational Leadership, 69(8), 30-34.

Jüttner, M., Boone, W., Park, S., \& Neuhaus, B. J. (2013). Development and use of a test instrument to measure biology teachers' content knowledge (CK) and pedagogical content knowledge (PCK). Educational Assessment, Evaluation and Accountability, 25(1), 45-67. http://dx.doi.org/10.1007/s11092-013-9157-y

Leatham, K., \& Peterson, B. (2010). Secondary mathematics cooperating teachers' perceptions of the purpose of student teaching. Journal of Mathematics Teacher Education, 13(2), 99-119. http://dx.doi.org/10.1007/s10857-009-9125-0

Lutwama, E., \& Kigongo-Bukenya, I. M. N. (2004). A tracer study of the East African school of library and information science graduates 1995-1999 working in Uganda. South African Journal of Libraries and Information Science, 70(2), 99-109.

Mainardes, E.W., Silva, M. J., \& Domingues, M. J. C. (2010). The development of new higher education courses. Service Business, 4(3-4), 271-288. http://dx.doi.org/10.1007/s11628-010-0095-1

National Wages and Productivity Commission. (2014). Current Daily Minimum Wage Rates Region VII. Retrieved April 1, 2014, from http://www.nwpc.dole.gov.ph/pages/rb-7/cmwr.html

Rohaan, E., Taconis, R., \& Jochems, W. (2012). Analysing teacher knowledge for technology education in primary schools. International Journal of Technology and Design Education, 22(3), 271-280. http://dx.doi.org/10.1007/s10798-010-9147-z

Romillo, J. P. E., \& Rodriguez, S. M. (2011). Emilio Aguinaldo college graduate tracer study (school year 2006-2007 to school year 2009 -2010). Emilio Aguinaldo College Research Bulletin, 10 (1).

Tschannen-Moran, M., \& McMaster, P. (2009). Sources of self-efficacy: Four professional development formats and their relationship to self-efficacy and implementation of a new teaching strategy. The Elementary School Journal, 110(2), 228-245. http://dx.doi.org/10.1086/605771 
Cañizares, M. J. F.

Velthuis, C., Fisser, P., \& Pieters, J. (2014). Teacher training and pre-service primary teachers' self-efficacy for science teaching. Journal of Science Teacher Education, 25(4), 445-464.

http://dx.doi.org/10.1007/s10972-013-9363-y

Yilmaz-Tuzun, O. (2008). Pre-service elementary teachers' beliefs about science teaching. Journal of Science Teacher Education, 192(2), 183-204. http://dx.doi.org/10.1007/s10972-007-9084-1

Ziebarth-bovill, J., Kritzer, J., \& Bovill, R. (2011).The essential criteria for hiring first year teacher candidates. Education, 133(1), 125-138. 